\title{
Knowledge and Practice of Informal Religious Leaders in Referring Tuberculosis Suspects to Visit Public Health Center
}

\author{
Imelda F.E. Manurung ${ }^{1, *}$, Helga J. Ndun ${ }^{2}$, Luh Putu Ruliati ${ }^{3}$, Aminah H. Baun ${ }^{4}$, \\ Yumiati Ke Lele ${ }^{5}$, Chatarina Wahyuni ${ }^{6}$ \\ ${ }^{1,2,3}$ Public Health Faculty, Nusa Cendana University Kupang, Indonesia \\ ${ }^{4}$ Health Office of East Nusa Tenggara Kupang, Indonesia \\ ${ }^{5}$ Health Office of Kupang City Kupang, Indonesia \\ ${ }^{6}$ Public Health Faculty, Universitas Airlangga, Surabaya, Indonesia \\ *Corresponding Author.Email: imelda.manurung@staf.undana.ac.id
}

\begin{abstract}
A majority of TB cases in East Nusa Tenggara (NTT) Province were found in Kupang City. This study aims to identify the influence of informal religious leaders (IRL) in finding and referring TB suspects. The research was a quasi-experimental one-group design with pre-test and post-test consisting of 2 stages. In stage 1, the intervention was a training given to religious leaders to increase the knowledge and practice of TB-case finding, and support for the referral of TB suspects using t-test. In stage 2, the effect of IRL support in identifying and assisting suspects to examine sputum; the effect was analyzed descriptively. The study population included all informal religious leaders living at the study site. The results found a significant increase in the mean value before and after training on the knowledge variable $(48.85 ; 88.48 ; \mathrm{p}=0.001)$ and the variable of TB suspect referral support $(39.93 ; 89.19 ; \mathrm{p}=0.001)$. The result also showed an increase in TB case visits to Public Health Care (PHC) before and after IRL support was given with the total of 30 and 77 people respectively. In conclusion, the interventions were effective in improving knowledge and support for IRL in referring TB suspects to have health examination at PHC.
\end{abstract}

Keywords: TB suspects, support, informal religious leaders

\section{INTRODUCTION}

The incidence of tuberculosis in 2016 reached 10.4 million cases (120 cases per 100,000 population) globally [1]. Indonesia was the third largest country in TB cases in the world after India and China [2]. Based on the report of the World Health Organization in 2017, 1,020,000 cases TB in Indonesia were estimated, but only 420,994 cases were reported [3]. Lung TB cases in East Nusa Tenggara Province (NTT) in 2017 reached 6,236 cases (118 per 100,000 population). This figure increased compared to 2016, which totaled 4,070 cases. The highest case of pulmonary TB in all districts/cities of NTT Province was Kupang City with 767 cases [4]. TB was an infectious disease caused by Mycobacterium Tuberculosis and could attack various organs of the human body [5], [6]. The most common cases of TB were pulmonary TB [7].

The challenge of TB control were related to particular factors including shame and the lack of support for TB patients from the community [8]. TB patients also often experienced stigma as the disease is highly contagious [9]. Failure of TB control could also be caused by the limited knowledge of early TB detection and non-compliance in taking medication due to forgetfulness and lack of support to motivate the recovery of patients [10]-[12]. Therefor, the support to strengthen and motivate TB suspects to have health examination is significant. The TB case finding program through a community approach using cadres had been carried out. However, TB cases continued to be an issue until now [13]. Involving the full potential of the community for TB control was a necessary alternative in dealing with the issue. Local support was the potential and resources possessed by an area to be used in achieving a certain goal [14]. Informal religious leaders were figures of local leadership in the society. The potential of the Province of NTT was the number of informal religious leaders contributing to solving health problems in the community. An informal religious figure was a person whom the community believed had the gift of curing illnesses and was able to help individuals cope with life's struggles, including diseases. The potential of informal religious leaders could be a supporting and hindering factor in TB prevention efforts in NTT Province [15]. The limited knowledge of religious leaders related to TB-case finding and treatment served as a barrier for the recovery of TB suspects who sought help from IRL [16]. Improving IRL knowledge and skills in providing support for suspected TB cases was critical in encouraging the suspects to obtain medical examination. A person could provide appropriate support if he had sufficient knowledge 
and skills [17]. Training on TB is effective in increasing knowledge and skills in the prevention of TB transmission [18], [19]. Local support would strengthen the motivation for finding suspected TB cases [20]. This study will identify the influence of the support from informal religious leaders in finding and referring TB suspects.

\section{METHOD}

This research was analytical with a quasi-experimental design approach with pre-test and post-test design [21]. The research was conducted in 2 stages. In stage 1, an intervention was carried out in the form of training to increase knowledge about TB and the practice of support for TB-case referral. Pre-test and post-test were given before and after the training. In stage 2, IRL identified, accompanied and referred TB suspects to take sputum examination at the Public Health Care (PHC) for one month. The locations of the study were Sikumana and Bakunase PHC as both had the highest TB cases in Kupang City [22]. The population and study sample included all IRL who resided at the study site as many as 35 people. IRL were individuals whom the community believed can provide healing based on faith in God. Pretest and post-test training was used to measure support knowledge and skills. Knowledge related to TB definitions, symptoms, examination, transmission, prevention and treatment were asked to find the level of IRL's knowledge. This knowledge questionnaire consisted of 7 questions with right and wrong choices. The support practice variable was related to information support, empathy, appraisal and instrument [23] containing 9 question items with the choice of 'yes and 'no'. Primary data collection to measure the increase in knowledge and skills in TB suspected support before and after training were analyzed using the t-test because data were normally distributed [24]. Secondary data collection was carried out to identify the effect of family and IRL assistance by comparing the number of suspected TB cases taking examinations at Sikumana and Bakunase PHC before and after the intervention. IRL provided a referral card to suspected TB cases as evidence to whether TB suspects had health examination due to the results of IRL support. Ethical clearance was conducted at the Faculty of Medicine, University of Nusa Cendana with the registration number UN01170883. Ethical clearance was conducted by asking respondents' willingness, and explanation of the impact and benefits of the research on

Table 1. Frequency Distribution of Respondent Characteristics

\begin{tabular}{|l|l|r|r|}
\hline Variable & Category & $\mathrm{f}$ & $\%$ \\
\hline Age & $\leq 30$ & 1 & 2.8 \\
& $31-40$ & 4 & 11.4 \\
& $41-50$ & 12 & 34.4 \\
& $>50$ & 18 & 51.5 \\
\hline Religion & Christian & & \\
& Catholic & 21 & 60.0 \\
& Islam & 9 & 25.7 \\
& Civil Servant/Pension & 12 & 14.2 \\
\hline Occupation & Entrepreneur & 14 & 40.2 \\
& Household mother & 9 & 25.7 \\
& & & \\
\hline
\end{tabular}

respondent as well as compensation of time to the respondent during the research process.

This research was conducted in the work area of Sikumana and Bakunase PHC in Kupang City. In 2017, most TB patients were found in both PHCs. The results of this study presented a descriptive analysis of the characteristics of respondents including age, occupation, religion and education. Bivariate analysis was applied to see differences in knowledge and support skills before and after training. In addition, a descriptive analysis was applied to identify the difference in the number of TB case visits in the targeted PHC at the time before and after IRL support. Based on table 1, the majority of religious leaders was Protestants, aged $>50$, entrepreneur, and graduated from senior high school.

Table 2. Descriptive Analysis

\begin{tabular}{|l|c|c|c|c|c|c|}
\hline Variable & \multicolumn{6}{|c|}{ Experiment } \\
\cline { 2 - 7 } & \multicolumn{5}{|c|}{ Pre } & \multicolumn{3}{c|}{ Post } \\
\cline { 2 - 7 } & Mean & Min & Max & Mean & Min & Max \\
\hline Knowledge & 48.85 & 14 & 57 & 88.48 & 71 & 100 \\
\hline $\begin{array}{l}\text { Support } \\
\text { practice }\end{array}$ & 39.93 & 22 & 56 & 83.50 & 67 & 100 \\
\hline
\end{tabular}

The increase in the value of knowledge and practice of support at the time before and after training can be seen in table 2 . The results of the descriptive analysis showed the score of knowledge of 35 respondents with a maximum score at the time before training of 14 and support practice of 22. The maximum score of knowledge and practice of support after training reached 100 .

Table 3. Bivariate Analysis

\begin{tabular}{|l|l|}
\hline Variable & p-value \\
\hline Knowledge & 0.001 \\
\hline Support practice & 0.001 \\
\hline TB suspect visits to PHC & \\
Before IRL support: 30 & \\
After IRL support: 77 & \\
BTA+: 5 & \\
\hline
\end{tabular}

\section{RESULTS AND DISCUSSION}

\section{Linier Regression}

In table 3 , the results of bivariate analysis showed p-value $<0.05$ suggesting a significant difference in the score of knowledge and support given by IRL before and after training. IRL support increased the visits of suspected TB cases to PHC. Before IRL support was provided, $30 \mathrm{~TB}$ suspects had visits to PHC and after IRL support, the number increased to 77 suspected cases. The results of laboratory tests on all suspected TB cases found five BTA positive. 
The results of this study indicated that there was a significant increase between the knowledge score and skills before and after training. It can be concluded that the training had a significant effect on increasing IRL knowledge and skills. TB training was effective in improving the knowledge about TB prevention [25] The training material provided was information about TB facts, transmission and prevention, skills in identifying suspected TB cases and skills in providing support to find and refer TB suspects. The results of the training increased IRL knowledge. The questions that were mostly answered incorrectly at the pre-test were that TB was caused by a 'witchcraft' disease that people sent and that TB transmission could occur through clothing or shaking hands.

All participants showed enthusiasm and actively gave answers and questions during the training. The participants were committed to the training seen from their punctuality and focus when the facilitator delivered the information. Participants were also enthusiastic to be involved in the practice session. Incorrect answers related to $\mathrm{TB}$ transmission and prevention given by the participants at the beginning of the material became correct after the posttest. Participants were also equipped with several practices to provide support for suspected TB cases. GMIT Synod figures provided motivation that IRL, as an extension of the church, should be more eager to run services properly related to the TB issue. Participants made an agreement within one month to look for a minimum of two suspected TB cases to be given support for having medical examination.

Knowledge and support practices were necessary to influence individuals on health practice [26]. A person with better knowledge about TB prevention would be more likely to prevent TB [27]. Adequate knowledge and good practice related to TB prevention were not only beneficial for IRL personally but also for improving IRL's skill in providing support for TB suspects to have health examination at PHCs. Support might be given in the form of information, empathy, appraisal and instrument support [28], [29]. In this study, IRL provided information support related to TB causes, symptoms, examinations, transmission and treatment to TB suspects. Support from influential people in the community was effective in encouraging individuals to practice healthy behavior [30], [31]. This can be proven from the research results in which IRL had increased the number of sputum examinations in suspected TB cases at PHCs.

\section{CONCLUSION}

An increase in knowledge and practice of support is observed after training for IRL. This results in a higher number of suspected TB cases taking medical examinations after IRL support is provided. The intervention is effective to improve the knowledge and practice of IRL support for suspected TB cases to have medical examination at PHCs.

\section{REFERENCES}

[1] World Health Organization. Global tuberculosis report 2017. Geneva: WHO; 2017. p.28-29.

[2] Kementrian Kesehatan Republik Indonesia. Pusat data dan informasi. Jakarta Selatan: Kementrian Kesehatan RI; 2018. p. 3-4.

[3] Dinas Kesehatan Provinsi Nusa Tenggara Timur. Profil Kesehatan Provinsi Nusa Tenggara Timur Tahun 2017. Kupang: Dinas Kesehatan Provinsi NTT; 2017. p.44.

[4] Dinas Kesehatan Provinsi Nusa Tenggara Timur. Profil Kesehatan Provinsi Nusa Tenggara Timur Tahun 2016. Kupang: Dinas Kesehatan Provinsi NTT; 2016. p.40.

[5] Barberis I, Bragazzi LN, Galluzzo L, Martini M. The history of tuberculosis: from historical records to the isolation of Koch's bacillus. Journal of Preventive Medicine and Hygiene. 2017; 58 (1): E9-E12.

[6] Churchyard G, Kim P, Shah SN, Rustomjee R, Gandhi N, Mathema B, et al. What we know about Tuberculosis Transmission: An overview. The Journal of Infectious Disease. 2017; 216 (6): S629-S635.

[7] Delogu G, Sali M, Fadda G. The biology of Mycobacterium Tuberculosis infection. Mediterranean Journal of Hematology and Infectiious Diseases. 2013; $5(1)$.

[8] Media Y. Pengetahuan, sikap dan perilaku masyarakat tentang penyakit Tuberkulosis (TB), Kecamatan Sungai Tarab, Kabupaten Tanah Datar Provinsi Sumatera barat. Media Litbang Kesehatan. 2011; 21(2): 82-88.

[9] Skinner D, Claassens M. It's complicated: why do Tuberculosis patients not initiate or stay adherent to treatment? A qualIRLtive study from South Africa. BMC Infectious Diseases. 2016; 16(1): 712.

[10] Craig MG, Daftary A, Engel N, O’Driscoll S, Ioannaki, A. Tuberculosis stigma as a social determinant of health: a systematic mapping review of research in low incidence countries. Internatinal Journal of Infectious Diseases. 2017; 56(2017): 90-100.

[11] Ali KM, Karanja S, Karama M. Factors associated with tuberculosis treatment outcomes among tuberculosis patients attending tuberculosis treatment centres in 2016-2017 in Mogadishu, Somalia. The Pan African Medical Journal. 2017; 28(197).

[12] Gebreweld HF, Kifle MM, Gebremicheal EF, Simel LL, Gezae MM, Ghebreyesus SS, et al. Factors influencing adherence to tuberculosis treatment in Asmara, 
Eritrea: a qualIRLtive study. Journal of Health, Population and Nutrition. 2018; 37(1): 1.

[13] Boru GC, Shimels T, Bilal IA. Factors contributing to non-adherence with treatment among TB patients in Sodo Woreda, Gurage Zone, Southern Ethiopia: A qualIRLtive study. Journal of Infections and Public Health. 2017; 10(5): 527-533.

[14] Global Health Campus. Stop TB Field guide 3: Finding missing people with TB in communities. Geneva: Global Health Campus; 2018. p.14-20.

[15] Manurung I, Wahyuni C, Probandari A. Effoat of health literacy to the empowered servant of God in supporting individuals at risk of HIV and AIDS to follow VCT. Internationa Journal of Sciences: Basic and Applied Research. 2016; 26(1); 231-236.

[16] Manurung I, Ruliati P, Ndun N, Baun A, Lele Y, Wahyuni U. God servants' knowledge and stigma of tuberculosis in Kupang Indenesia. Public Health of Indonesia. 2018; 4(3):116-120.

[17] Manurung I, Wahyuni C, Notobroto $\mathrm{H}$. Enhancement HIV health literacy at servant of God in providing support for individual at risk of HIV for following VCT in Province of NTT. International Journal of Sciences: Basic and Applied Research. 2016; 29(1): 124-129.

[18] Alanazi A. The us of simulation training to improve knowledge, skills, and confidence among healthcare students: a systematic review. The Internet Journal of Allied Health Sciences and Practise. 2017; 15(3).

[19] Scott C, Mangan J, Tilova Z, Jensen P, Ahmedov S, Ismoolova $\mathrm{J}$, Trusov A. Evaluation of the tuberculosis infection control training center, Tajikistan, 2014-2015. International Journal Tuberculosis Lung Diseases. 2017;21(5): 579-585.

[20] Potter J, Inamdar L, Okereke E, Collinson S, Dukes R, Mandelbaum M. Support of vulnerable patient throughout TB treatment in the UK. Journal of Public Health. 2015; 38(2): 391-395.

[21] Sugiyono. Metode penelitian pendidikan pedekatan kuantIRLtif, kualIRLtif, dan R \& D. Bandung: Alfabeta; 2014. p.77.
[22] Dinas Kesehatan Kota Kupang. Laporan Pengelola program TB Kota Kupang 2017.

[23] Laird Y, Fawkner S, Kelly P, McNamme L, Niven A. The role of social support on physical activity behavior in adolescent girls: a systematic review and meta-analysis. International Journal of Behavioral Nutrition and Physical Activity. 2016; 13(79).

[24] Riwidikdo H. Statistika Kesehatan. Yogyakarta: Rohima Press; 2013. p.125.

[25] Boy E. EfektifIRLs pelatihan kader kesehatan dalam penanganan tuberculosis di wilayah binaan. Jurnal Pendidikan Kedokteran Indonesia. 2015; 4(2); 83-89.

[26] Castro-Sanchez E, Chang P, Vila-Candel R, Escobedo A, Holmes A. Helath literacy and infectious diseases: why does it metter? International Journal of Infectious Diseases. 2016; 43(2016): 103-110.

[27] Rensburg A, Engelbrecht M, Kigozi G, Rensburg D. Tuberculosis prevention knowledge, attitudes, and practices of primary health care nurses. International Journal of Nursing Practice. 2018; 24(6).

[28] Li X, Wang B, Tan D, Li M, Zhang D, Tang C, et al. Effectiveness of comprehensive social support interventions among elderly patients with tuberculosis in communities in China: a community-based trial. Journal of Epidemiology and Community Health. 2018; 72(5): 369375.

[29] Glanz K, Rimer B, Viswanath K. Health behavior and health education. San Fransisco: Jossey-Bass; 2008. p. 189-207.

[30] Saputra A, Sary N. Konseling model transteoritik dalam perubahan perilaku merokok pada remaja. Jurnal Kesehatan Masyarakat Nasional. 2013; 8(4): 152-157.

[31] Choiriyah M, Hapsari E, Lismidiati W. Tradisi dan lingkungan sosial memengaruhi dukungan menyusui pada bayi berat badan lahir rendah di Kota Malang. Jurnal Kesehatan Masyrakat Nasional. 2015; 10(1): 37-43. 